\title{
PUDARNYA KAIDAH KESANTUNAN PADA MASYARAKAT INDONESIA
}

\author{
Muhamad Rinzat Iriyansah dan Hilda Hilaliyah \\ Unindra PGRI \\ rinzat@gmail.com, hilda.unindra@gmail.com
}

\begin{abstract}
ABSTRAK
Penelitian ini bertujuan untuk mendeskripsikan pudarnya kaidah kesantunan masyarakat Indonesia ketika bertutur kata. Penelitian ini menggunakan pendekatan kualitatif. Dalam tahap penyediaan data, penelitian ini menggunakan metode simak. Data bersifat alamiah yang bersumber pada komentar yang dilakukan oleh masyarakat Indonesia dalam berita daring. Hasil penelitian menunjukan banyaknya tuturan tidak santun yang dilakukan oleh masyarakat Indonesia dalam berkomentar menanggapi berita aktual. Komentar tersebut menggunakan strategi (1) ketidaksantunan positif dan (2) ketidaksantunan negatif. Ketidaksantunan positif terbagi menjadi 8 maksim sedangkan ketidaksantunan negatif terbagi menjadi 2 maksim.
\end{abstract}

ABSTRACT

Kata Kunci : kesantunan, ketidaksantunan, muka positif, muka negatif

This study aims to describe the fading of the rules of politeness of Indonesian society when speaking. This research uses qualitative approach. In the data supply stage, this research uses the method refer to. The data are natural in nature derived from comments made by the Indonesian people in the online news. The result of the research shows the number of irreverent speeches conducted by the Indonesian people in commenting on the actual news. The comments use strategy (1) positive impoliteness and (2) negative impoliteness. Positive impoliteness is divided into 8 maxims whereas negative impoliteness is divided into second maxims.

Keywords : politeness, impoliteness, positive face, negative face

PENDAHULUAN

Bangsa Indonesia dihuni oleh masyarakat yang heterogen. Keheterogenan tersebut tidak melepaskan masyarakat Indonesia pada karakternya yang terkenal dengan kesantunannya yakni suka menolong, gotong-royong, empati, dan toleransi. Terutama pada kesantunan berbahasa. Bahasa Indonesia merupakan produk terbesar dari sebuah bangsa. Bahasa merupakan salah satu unsur kebudayaan universal yang berperan penting dalam kehidupan masyarakat (Iriyansah, 2017:60). Bahasa Indonesia merupakan alat komunikasi yang berperan penting dalam kehidupan masyarakat Indonesia yang multilungual.

Dewasa ini, kesantunan masyarakat Indonesia sudah mulai pudar. Hal tersebut terlihat dari bagaimana masyarakat Indonesia bersikap dalam menghadapi fenomena yang sedang terjadi. Sering kali masyarakatnya dalam bertindak tidak dipikirkan terlebih 
dahulu terutama pada kalangan generasi muda. Apalagi dalam menyikapi berita hoax. Masyarakat kita mudah sekali terpancing emosinya sehingga tuturan tidak santun sering kali terucap.

Perkembangan suatu bahasa tidak akan lepas dari perkembangan budaya masyarakat penduduknya. Menurut Nababan (dalam ziaulhaq, 2017:124) menyatakan bahwa kebudayaan adalah system aturan kominkasi dan interaksi yang memungkinkan suatu masyarakat terjadi, dipelihara, dan dilestarikan. Perkembangan teknologi yang pesat membawa dampak negatif yang signifikan terhadap perkembangan budaya di Indonesia. Nilai budaya erat terkait dengan nilai etika yang diyakini oleh masyarakat pendukungnya. Setiap budaya memiliki indikator kesantunan yang berbeda. Penggunaan bahasa tidak terlepas dari konteks dan koteksnya. Menurut Leech (1983:13) "background knowledge assumed to be shared by $s$ and $h$ and which contributes to h's interpretation of what s means by a given utterance". Dengan demikian, konteks adalah hal-hal yang bergantung dengan lingkungan sosial sebuah tuturan ataupun latar belakang pengetahuan yang sama-sama dimiliki oleh penutur dan lawan tutur dan yang membantu lawan tutur menafsirkan makna tuturan.

Lakoff (1972) berpendapat bahwa ada tiga kaidah yang perlu dipatuhi agar ujaran kita terdengar santun oleh penutur dan mitra tutur kita. Ketiga kaidah itu adalah formalitas (formality), ketaktegasan (hesitancy), dan persamaan atau kesekawanan (equality or camaraderie). Jika dijabarkan kaidah yang pertama itu berarti "jangan memaksakan atau jangan angkuh (aloof), yang kedua berarti "buatlah sedemikian rupa sehingga lawan bicara anda dapat menentukan pilihan, dan yang ketiga bermakna "bertindaklah seolah-olah anda dan lawan bicara anda sama atau dengan kata lain buatlah ia merasa senang”. Dengan demikian, ujaran dalam tuturan itu memberi pilihan tindakan kepada mitra tutur dan mitra tutur menjadi senang. Sebagai gambaran awal mengenai prinsip kesantunan Lakoff (1972).

Kaidah ketimuran yang melekat dengan masyarakat Indonesia lambat laun sudah mulai pudar. Hal ini dapat terlihat dari berbagai ujaran yang diucapkan secara tidak santun oleh masyarakat Indonesia terutama dalam dunia daring. Komentar-komentar yang diberikan oleh warganet banyak yang terindikasi melanggar norma kesantunan berbahasa. Sebagai contoh :

Murdawi akhir : banyak retorika ini anies.. nyesel dulu pilih anies.. hedeh...

Contoh di atas merupakan komentar atas berita yang berjudul “Fakta-FaktaTim Gubernur Versi Anis Senilai 28M.” (detik.com) Komentar tersebut berkaitan dengan temuan Tim Gubernur yang nominalnya cukup fantastis yakni 28M. Penutur langsung merespon berita tersebut dengan maksim penghinaan. Penutur menganggap gubernur Jakarta yang baru hanya pandai beretorika.

Komentar dengan bentuk yang tidak santun sering sekali ditemukan terutama dalam mengomentari berita daring. Terdapat berbagai macam strategi yang digunakan oleh masyarakat 
Indonesia dalam bertutur secara tidak santun. Culpeper (1996) mengembangkan konsep strategi ketidaksantunan sebagai strategi yang berlawanan dengan strategi kesantunan menurut Brown dan Levinson (1987), yaitu strategi (a) bald on record impoliteness yaitu strategi ketidaksantunan yang sengaja dilakukan dengan terus terang tanpa menghiraukan muka mitra tutur, (b) positive impoliteness yaitu strategi yang sengaja untuk mengancam muka positif mitra tutur, (c) negative impoliteness merupakan strategi yang sengaja ditujukan untuk mengancam muka negatif mitra tutur, (d) mock politeness, yaitu strategi kesantunan semu atau purapura, (e) withhold politeness yaitu ketidaksantunan terjadi disebabkan oleh tidak adanya kesantunan yang semestinya ada. Semakin hari komentar ketidaksantunan dalam jaringan internet semakin bertambah. Jika hal tersebut tidak diperbaiki maka ketidaksantunan bukan hal yang tabu lagi bagi masyarakat Indonesia. Padahal, norma sosiokultural menghendaki agar manusia bersikap santun dalam berinteraksi dengan sesamanya.

\section{METODE}

Penelitian ini menggunakan metode kualitatif. Menurut Chaedar Alwasilah (2002:23) dalam penelitian kualitatif perilaku responden dilihat dalam konteks tertentu dan pengaruh konteks terhadap tingkah laku tersebut.

Metode yang digunakan dalam tahapan penyediaan data penelitian ini menggunakan metode simak. Metode simak (Mahsun, 2007: 242) adalah metode yang digunakan dalam penyediaan data dengan cara peneliti melakukan penyimakan penggunaan bahasa. Metode ini memiliki teknik dasar yaitu teknik sadap. Dalam praktik penelitian, penyimakan dilakukan dengan menyadap penggunaan bahasa dari informan.

Teknik analisis data yang digunakan dalam penelitian ini yaitu padan intralingual dan padan ekstralingua.. Metode padan intralingual digunakan untuk menghubung-bandingkan unsur-unsur dalam data penelitian yaitu satuan lingual yang mengandung leksem ketidaksantunan untuk mendapatkan kesamaan hal pokok dari data-data tersebut. Hasil analisis ini akan menunjukkan intensites bidal ketidaksantunan yang sering digunakan oleh waganet dalam berkomentar terutama pada laman viva Metode yang kedua yaitu metode padan ekstralingual. Metode padan ekstralingual digunakan untuk menganalisis unsur yang bersifat ekstralingual, seperti menghubungkan masalah bahasa dengan hal yang berada di luar bahasa. Metode padan ekstralingual digunakan dalam penelitian ini untuk menganalisis penggunaan bahasa sesuai atau tidak dengan koteksnya. Hasil analisis akan menunjukkan ketidaksantunan bahasa yang digunakan oleh warganet dalam menanggapi berita pada laman viva news dan detik.com dari bulan Agustus 2017 s.d. Oktober 2017.

Berdasarkan hasil penelitian dari 69 data ketidaksantunan yang diperoleh dari komentar warganet pada laman viva news dan detik.com pada kurun waktu Agustus s.d. Oktober 2017 terdapat 2 
strategi yang digunakan dalam pengutaraan ketidaksantunannya yakni ketidaksantunan postif dengan jumlah $75 \%$ dan ketidaksantunan negatif dengan jumlah 25\%. Ketidaksantunan postif terbanyak ada pada penggunaan maksim penghinaan sedangkan ketidaksantunan negatif terbanyak pada penggunaan maksim kebencian

\section{Positive Pollitenes \\ Maksim Penghinaan}

Maksim penghinaan adalah maksim yang terwujud melalui penggunaan ungkapan yang bagi si lawan tutur dianggap sebagai menghina atau merendahkan lawan tutur. Berikut contoh ungkapan yang termasuk dalam maksim penghinaan

(1) Tidak pernah makan bangku kuliah. IQ nya berapa ya???

(2) Joni ersantroke : sombong! sok pintar!

Kalimat (1) merupakan komentar dari berita pada laman detik.com bulan Agustus 2017 yang berjudul "Dewi Persik Terobos Jalur Busway”. Komentar tersebut berisi penghinaan. Penutur menganggap tingkat intelektual mitra tutur rendah. Hal tersebut terlihat dari penggunaan kata 'tidak pernah makan bangku sekolah' yang secara jelas menghina mitra tutur dengan menganggap mitra tutur tidak pernah sekolah.

Kalimat (2) merupakan komentar dari berita yang berjudul “Jadi Tersangka, Ahmad Dhani: SARA Mana yang Dihina?”. Pada komentar tersebut penutur secara jelas menghina mitra tutur dengan mengungkapkan kata makian yakni 'sombong'.

\section{Maksim Penolakan}

Maksim penolakan adalah maksim yang terwujud melalui ungkapan-ungkapan yang bagi si penerima dipahami sebagai sebuah ketidaksetujuan. Berikut contoh penggunaan maksim penolakan yang dilakukan oleh warganet:

(3) Andre1207 :Wowo berapa kali nyapres tapi gak pernah berhasil krn memang gak pernah dapat restu dari Tuhan, begitu juga dgn cagub jatim Kofifah. Memang gak ada restunya.

Kalimat (3) merupakan komentar dari berita yang berjudul "Gerindra Dibuat Kaget dengan Elektabilitas Jokowi”. Berita tersebut berisi tentang meningkatnya popularitas Jokowi dan rendahnya popularitas Prabowo. Penutur menyatakan penolakan terhadap ketua umum Gerindra yakni Prabowo untuk maju menjadi president RI. Hal itu terlihat dari komentar ketidaksantunan penutur dengan menggunakan maksim penolakan. Ungkapan 'gak pernah dapat restu dari tuhan' memastikan bahwa penutur menolak prabowo untuk menjadi presiden. 


\section{Maksim Kesombongan}

Maksim kesombongan adalah maksim yang terwujud melalui penggunaan ungkapan yang bersifat merendahkan mitra tutur. Maksim kesombongan terdiri dari menjelkan dan merendahkan mitra tutur. Berikut contoh penggunaan maksim kesombongan yang dilakukan oleh warganet:

(4) Moro dio: Prabowo 30\% apa sudah hebat?? Pak Jokowi tanpa isu sara sudah bisa 53\% itu tanda rakyat sudah bias merasakan hasil kerja pak jokowi

(5) Allshopscenter : Lha terus kerjamu itu ngapain? Harusnya sebelum jadi rame kamu duluan yg menolak/menghapusnya... jadilah org yg tega

Kalimat (4) merupakan komentar dari berita yang berjudul "Gerindra Dibuat Kaget dengan Elektabilitas Jokowi”. Berita tersebut berisi tentang meningkatnya popularitas Jokowi dan rendahnya popularitas Prabowo. Pada komentar tersebut penutur berusaha memperlihatkan kesombongannya dengan merendahkan orang lain. Hal tersebut terlihat dari penggunaan maksim kesombongan dalam komentarnya yakni 'Prabowo 30\% apa sudah hebat'.

Kalimat (5) merupakan komentar dari berita yang berjudul "Anggaran Kolam DPRD Di Coret, Sandi: Alhamdulillah itu Uang Rakyat”. Berita tersebut berisi pencoretan anggaran pembuatan kolam dalam RAPBN. Respon penutur terhadap berita tersebut menyatakan kekecewaan atas kinerja anis-sandi yang tidak mampu mencoret anggaran yang tidak diperlukan. Penutur menggunakan maksim kesombongan dalam komentarnya yakni penggunaan kata 'Lha terus kerjamu ngapain?”. Ungkapan tersebut seolah penutur mampu bekerja lebih baik.

\section{Maksim Keemosionalan}

Maksim keemosionalan adalah maksim yang terwujud melalui ungkapan-ungkapan yang bagi lawan tutur dipahami sebagai wujud dari keemosionalan penutur. Maksim ini menyebabkan lawan tutur menjadi terancam akibat dari tuturan penutur. Berikut contoh penggunaan maksim keemosionalan yang dilakukan oleh warganet:

(6) Tom cabello : Jakarta lagi ngelawak ya, apalagi bosnya :)

Kalimat (6) merupakan komentar dari berita yang berjudul “Fakta-Fakta Tim Gubernur Versi Anis Senilai 28M”. Berita tersebut berisi tentang analisis gubernur Jakarta dalam pembentukan tim ubernur untuk mengatasi masalah di Jakarta. Penutur merasa kecewa terhadap kinerja gubernur terpilih yang baru. Ia mengungkapkan keemosionalannya dengan menggunakan perlokusi.

\section{Maksim Ketabuan}

Maksim ketabuan adalah maksim yang terwujud melalui ungkapan-ungkapan yang bagi lawan tutur tuturan tersebut 
merupakan pelanggaran atau ungkapan yang dirasa tabu untuk dituturkan. Akibat dari tuturan tersebut lawan tutur menjadi tidak nyaman dan merasa marah. Berikut contoh penggunaan maksim ketabuan yang dilakukan oleh warganet:

(7) Andik wahyunarto: Buktikan kehebatan mulutmu gandeng ama junjunganmu PS di Pilpres 2019.....itu baru gantle....kali ga mampu ......Impoten loe

Kalimat (7) merupakan komentar dari berita "Amin Rais: Saya Ingatkan Mas Jokowi, Jangan Asik Memecah Belah Umat”. Berita tersebut berisi pernyataan dari Amin Rais atas anggapan beliau bahwa Jokowi sebagai biang dari perpecahan umat. Respon dari penutur atas berita tersebut mengungkapkan kemarahannya. Hal itu terlihat dari tuturan yang tidak santun dengan pemarkah maksim ketabuan. Penutur berusaha merendahkan lawan tuturnya dengan menggunakan kata-kata yang tabu yakni 'impoten lo’.

\section{Maksim Pengabaian}

Maksim pengabaian adalah maksim yang terwujud melalui ungkapan-ungkapan yang bagi lawan tutur merasa tuturannya diabaikan atau tidak dihiraukan. Berikut contoh penggunaan maksim pengabaian yang dilakukan oleh warganet:

(8) ENNY DARMAWAN : Anis bilang Derita loo.

Kalimat (8) merupakan komentar dari berita "Tolong Pak Anis, Tanggul Kali Pulo Jatipadang Jebol Lagi” berita tersebut berisi informative mengenai jebolnya tanggul kali yang berada di jatipadang. Jika tidak segera ditangani bukan hal yang mustahil musibah banjir mengancam daerah tersebut. Penutur mengungkapkan ketidaksantunannya dengan menggunakan maksim pengabaian. Pada kata ‘derita lo' tidak ada hubungannya terhadap komentar berita tersebut.

\section{Maksim Salah Penyapaan}

Maksim salah penyapaan adalah maksim yang terwujud melalui bentuk penyapaan yang keliru yang diutarakan penutur kepada lawan tutur. Sapaan tersebut baik dari kekerabatan, gelar, jabatan, dll dirasa tidak sesuai dengan lawan tutur. Berikut contoh penggunaan maksim salah penyapaan yang dilakukan oleh warganet:

(9) Warga baik: Pak tua sudahlah, sudah pikun juga stres, nikmati saja masa tua dengan tenang, jangan lupa obat wasir dan encok diminum tiap hari

Kalimat (9) merupakan komentar dari berita “Amin Rais: Saya Ingatkan Kepada Mas Jokowi Jangan Asik Memecah Belah Umat”. Penutur berusaha merendahkan lawan tutur dengan menggunakan maksim penyapaan yang keliru. Penggunaan kata 'Pak Tua' merujuk pada Bapak Amin Rais yang memang usianya sudah tidak muda lagi. Kata sapaan tersebut bermaksud untuk merendahkan lawan tutur. 


\section{Maksim SARA}

Maksim SARA adalah maksim yang terwujud melalui ungkapan-ungkapan yang dilakukan oleh penutur kepada mitra tutur yang berkaitan dengan sikap diskriminatif terhadap suatu golongan. Berikut contoh penggunaan maksim SARA yang dilakukan oleh warganet:

\section{(10)Berkata jujur : AWAS YA KALAU NAMA MONAS} DIGANTI MENJADI MONSARA !

Kalimat (10) merupakan komentar dari berita yang berjudul “Taussiah Kebangsaan Di Monas, Anis: Lapangan Ini Milik Warga DKI”. Berita tersebut berisi Tausiah Gubernur Anis Baswedan pada saat masyarakat jakarta berkumpul di monas. Penutur berkomentar secara tidak santun dengan menggunakan maksim Sara yakni penggunaan kata 'MONSARA' pada komentarnya yang berarti monumen SARA.

\section{Negative Pollitenes}

\section{Maksim Kebencian}

Maksim kebencian adalah maksim yang terwujud melalui ungkapan-ungkapan yang digunakan oleh penutur terhadap lawan tutur yang dianggap sebagai ekspresi negatif yang melanggar hak lawan tutur. Berikut contoh penggunaan maksim kebencian yang dilakukan oleh warganet:

(11)Joni ersantroke : sombong ! sok pintar !

(12)Murdawi akhir : banyak retorika ini anies.. nyesel dulu pilih anies.. hedeh..

Kalimat (11) merupakan komatar dari berita yang berjudul “ Jadi Tersangka, Ahmad Dhani: SARA Mana yang Dihina?”. Berita tersebut berisi Ahmad Dhani ditetapkan menjadi tersangkan atas pasal penghinaan yang dilakukan olehnya. Penutur berusaha mengungkapkan kebenciannya terhadap lawan tutur yakni Ahmad Dhani. Hal tersebut terlihat dari komentarnya yang menggunakan bahasa tidak santun dengan maksim kebencian yakni pada kata 'sok pintar'.

Kalimat (12) merupakan komentar dari berita yang berjudul “ Fakta-Fakta Tim Gubernur Versi Anis Senilai 28M”. Berita tersebut berisi tentang rencana gubernur Anis Baswedan untuk membuat tim gubernur yang operasionalnya menggunakan anggaran APBD DKI senilai 28M. Penutur berusaha merendahkan lawan tutur dengan menggunakan maksim kebencian. Hal tersebut terlihat pada komentarnya yakni pada kata 'banyak retorika' dan 'nyesel'. Ungkapan tersebut jelas bermakna kebencian lawan tutur karena telah dibohongi oleh retorika Anis dan pengungkapan penyesalannya.

\section{Maksim Perintah}

Maksim perintah adalah maksim yang terwujud dari ungkapanungkapan yang digunakan oleh penutur kepada lawan tutur yang 
dimaknai sebagai perintah sehingga mengancam muka lawan tutur. Berikut contoh penggunaan maksim perintah yang dilakukan oleh warganet:

(13)Jansen kusumawardhana : Mending cepat mundur aja, biar kinerja Kemsos nggak terpengaruh

(14)Ranran1901 : Daripada bikin kongres ga jelas, mending bantuin yg di Pulo Jatipadang sono. Tunjukin donk kekompakannya. masa cuma kompak demo doank

Kalimat (13) merupakan komentar dari berita yang berjudul "Sudah Surati dan Temui Jokowi, Khofifah Mundur dari Mensos". Berita tersebut berisi tentang rencana pengunduran diri Khofifah sebagai Mensos karena rencana pencalonan dirinya sebagai gubernur Jawa Timur. Penutur mengungkapkan ungkapan tidak santun dengan menggunakan maksim perintah yakni pada kata "mending cepat mundur". Kata tersebut jelas bermakna perintah untuk segera mundur dari kursi kementrian sosial.

Kalimat (14) merupakan komentar dari berita yang berjudul “Beredar Dana Reuni 212 Rp443 Juta, Panitia Duit dari Mana?”. Berita tersebut berisi tentang rencana yang dilakukan oleh umat islam untuk melakukan reuni 212 di Monas. Penutur mengungkapkan ketidaksantunannya dengan menggunakan maksim perintah yakni pada kata 'bantuin yang di pulo jatipadang sono'. Kalimat tersebut bermakna penutur meminta lawan tutur dari pada melakukan reuni dengan anggaran yang besar mending melakukan kegiatan bantuan untuk jebolnya tanggul yang ada di pulo jatipadang.

Wujud ketidaksantunan berbahasa yang digunakan oleh warganet pada komentar berita daring sebanyak 2 strategi yaitu positive impollitenes dan negative impolitenes. Kategori positive impolitenes meliputi (1) maksim penghinaan, (2) maksim penolakan, (3) maksim keemosionalan, (4) maksim ketabuan, (5) maksim kesombongan, (6) maksim SARA, (7) maksim pengabaian, dan (8) maksim penyapaan. Kategori negative impolitenes meliput (1) maksim perintah dan (2) maksim kebencian. Dari hasil analisis data menunjukan bahwa maksim penghinaan merupakan kategori maksim yang paling sering digunakan oleh warganet dalam mengungkapkan ketidaksantunannya yakni sejumlah 19\%.

Dari hasil penelitian ini penulis menyampaikan beberapa saran sebagai berikut, (1) Hasil penelitian ini dapat digunakan sebagai referensi bagi pembinaan bahasa terutama tentang ketidaksantunan berbahasa sehingga para pengguna bahasa dapat santun dalam berbicara, (2) Hasil penelitian ini dapat dijadikan informasi bagi penelitian ketidaksantunan yang lain, (3) Hasil penelitian ini dapat dijadikan salah satu acuan berbahasa secara santun yaitu dengan menghindari penggunaan maksim ketidaksantunan dan mengedepankan prinsip kesantunan, strategi kesantunan dan skala kesantunan dalam berbahasa sesuai dengan situasi tutur. 
DAFTAR PUSTAKA

Alwasilah, Chaedar. 2002. Pokoknya Kualitatif, Dasar-Dasar Merancang dan Melakukan Penelitian Kualitatif. Jakarta : Dunia Pustaka Jaya.

Culpeper, J. 1996. 'Towards an Anatomy of impoliteness', Journal of Pragmatics 25, 349-367

Iriyansah, M. R. (2017). Sistem Sapaan Kerabat Keraton Surakarta Hadiningrat. FON, 11(2), 60-70. Retrieved from https://journal.uniku.ac.id/index.p $\mathrm{hp} / \mathrm{FON}$

Lakoff, R.T. 1975. Language and Women's Place. NY: Harper Colophom.
Levinson. Stephen C., 1983. Pragmatics. London: Cambridge University Press.

Mahsun. 2007. Metode Penelitian Bahasa Tahapan, Strategi, Metode, dan Tekniknya. Jakarta: Grafindo Persada

Setiyanto, Edi. 2012. Ketaksantunan Komentar Pada Laman Berita Yahoo. Jurnal Ranah vol.1 no. 2. Jakarta. Badan bahasa

Ziaulhaq. 2017. Ragam Bahasa dan Strategi Tindak Tutur Pedagang Asongan di Terminal Purabaya Kota Surabaya. Jurnal Lingua Franca Vol. 5 No.2 2017. 